\title{
Prevalence and Antimicrobial Susceptibility of Salmonella Serotypes in Patients from Ribeirão Preto, São Paulo, Brazil, between 1985 and 1999
}

Fabíola Attié de Castro, Vanda Roseli dos Santos, Carlos H. Gomes Martins, Sueli A. Fernandes, José Eduardo Zaia and Roberto Martinez
School of Pharmacy of Ribeirão Preto, University of São Paulo; Clinical Hospital of the School of Medicine of Ribeirão Preto, University of São Paulo; University of Franca, São Paulo; Adolfo Lutz Institute, São Paulo, Department of Internal Medicine, School of Medicine of Ribeirão Preto, SP, Brazil

Salmonella strains isolated from 1,138 samples representing 28,199 biological materials (stool, urine, blood and other fluids), collected between January 1985 and January 1999 at a reference University Hospital in Ribeirão Preto, São Paulo, Brazil, were studied. The most frequently detected serotypes were Salmonella enterica subspecies enterica serotype 4,5,12:i:(S. I 4,5,12:i:) (21.2\%), S. agona (15.8\%) and S. enteritidis (11.3\%). A changing pattern of Salmonella serotypes was observed between 1985-1999. S. agona, which represented $27 \%$ of Salmonella serotypes isolated from 1985-1989, declined to $4 \%$ during the period from 1995 to 1999. S. enteritidis isolation remained below $1 \%$ until 1989 ; rose to $5.9 \%$ between 1990 and 1994, and increased to $32.3 \%$ between 1995-1999. S. I 4,5,12:i:-; S. enteritidis; S. typhimurium; $S$. dublin and $S$. infantis, showed low to moderate resistance profiles to most antimicrobial drugs. Nalidixic acid and tetracycline were the most and the least effective drugs, respectively, in the disk diffusion tests. We encountered changes in salmonellosis epidemiology in this geographical region.

Key Words: Salmonella, salmonellosis, serotypes, epidemiology and gastroenteritis.

In Brazil and in other developing countries human salmonellosis continues to be a major public health problem [1-8]. Salmonella is an enteropathogenic microorganism that causes infection accompanied by different clinical manifestations, most commonly gastroenteritis. Along with genuine systemic salmonellosis (typhoid and paratyphoid fever), salmonella infections in humans are mainly food-borne. More than 2,300 Salmonella serotypes have been

Received on 19 April 2002; revised 27 August 2002.

Address for correspondence: Dr. Profa. Fabíola Attié de Castro. Faculdade de Ciências Farmacêuticas de Ribeirão Preto, Departamento de Análises Clínicas, Toxicológicas e Bromatológicas. Av. do Café s/n, Zip code: 14040-903, Ribeirão Preto, São Paulo, Brasil. Phone. +5516-602-4220 Fax. +5516633-1936.E-mail: castrofabiola@hotmail.com

The Brazilian Journal of Infectious Diseases 2002;6(5):244-251 (C) 2002 by The Brazilian Journal of Infectious Diseases and Contexto Publishing. All rights reserved.

1413-8670 described, but only some of them, such as $S$. typhimurium, S. enteritidis, $S$. choleraesuis, $S$. hadar, $S$. virchow, and $S$. dublin among others, play important epidemiological-epizootiological roles [9]. Although the mortality rate linked to salmonellosis is low, its high prevalence has significant economical, epidemiological and health implications [10-11].

Serotyping and molecular methods are important epidemiological tools for determining sources of infection, and serotyping has been used as an epidemiological marker for the study of Salmonella spp infection in a given population and location at a given time [12-15].

The aim of our study was to make a comprehensive analysis of the epidemiology of salmonellosis in the northeastern São Paulo state, Brazil. We determined the predominant serotypes and the resistance profile of Salmonella spp. strains isolated from patients attended over a period of 15 years (1985-1999) at the reference 
University Hospital of the School of Medicine of Ribeirão Preto of the University of São Paulo, Brazil, which receives patients from approximately 18 different cities of this region of São Paulo state.

\section{Material and Methods}

Study sample

A retrospective analysis was made of all records of Salmonella spp. isolations from the Microbiology Laboratory of the Emergency Unit of University Hospital, Ribeirão Preto School of Medicine, University of São Paulo - Brazil, taken from January 1985 to January 1999. The 1,138 Salmonella strains, (Table 1), were isolated from 864 stool samples, 167 blood samples, 32 urine samples and 75 samples from other fluids (exudates, bile, cerebrospinal and synovial fluids), from 28,199 clinical samples.

Stool samples were routinely cultured on MacConkey agar, Salmonella-Shigella agar (SS) and Selenite F broth. Media were incubated overnight at $37^{\circ} \mathrm{C}$ and nonfermenting lactose colonies of different morphologic types growing on SS agar or MacConkey agar plates were identified on the basis of their biochemical properties. Specimens from other fluids (blood, urine and other fluids) were cultured using Brain Heart Infusion (BHI) - for blood, Cystine-LactoseElectrolyte-Deficientagar(CLED) - for urine, and blood agar and chocolate agar - for other fluids. Inoculation and incubation were performed by standard procedures [16]. When morphological aspects suggested Salmonella spp., colonies were investigated by biochemical tests. The biochemical properties of isolated colonies were evaluated as described by Ewing [17]. At least three colonies having a typical appearance of Salmonella were chosen and applied in triplicate to triple sugar and iron and lysine iron agar slants, and incubated overnight at $37^{\circ} \mathrm{C}$.

Agglutination tests

Colonies considered to be Salmonella as a result of biochemical testing, were investigated for $\mathrm{O}$ and $\mathrm{H}$ antigens using polyclonal antibodies and diagnostic anti$\mathrm{O}$ and anti-H antisera (Probac, Brazil). These antigens were determined by the slide agglutination test.

Serotyping

All strains were serotyped according to the method described previously [18] at the Laboratory of Enteric Pathogens, Instituto Adolfo Lutz - São Paulo, Brazil.

\section{Drug resistance assays}

Antimicrobial susceptibility tests were done by the disk diffusion method by the standard methods outlined by the National Committee for Clinical Laboratory Standards (NCCLS) [19]. Three to five colonies were introduced into a tube containing trypticase soy broth, incubated overnight, and the broth cultures diluted until turbidity matched a $0.5 \mathrm{McF}$ arland turbidity standard. Petri dishes with Mueller-Hinton agarwere used for the sensitivity tests. Plates were dried for approximately 30 minutes prior to inoculation, and used within 1 day following preparation. Bacterial broth suspensions were streaked on the surface of media with a cotton swab. After the inoculum had dried, theantimicrobial disks were placed on the agar using flamed forceps, and gently pressed down to ensure contact. Disks with the following antibiotics (diffusible amounts) were provided from a commercial source (Ceccon): amikacin

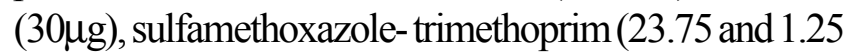
mg, respectively), ampicillin $(10 \mu \mathrm{g})$, tetracycline $(30 \mu \mathrm{g})$, tobramycin $(10 \mu \mathrm{g})$, cefoxitin $(30 \mu \mathrm{g})$, cephalothin $(30 \mu \mathrm{g})$, chloramphenicol $(30 \mathrm{mg})$, nalidixic acid $(30 \mu \mathrm{g})$ and gentamicin $(10 \mu \mathrm{g})$.

Statistical analysis

Differences in Salmonella serotype prevalence over three, 5-year intervals (1985 to 1989; 1990 to 1994 and 1995 to 1999 periods), were compared using the chi square test [20]. The test was applied only for the most prevalent serotypes found in our study namely, $S$. I 4,5,12:i:-, S. agona, S. enteritidis and $S$. typhimurium. Chi square values were obtained using STATDISK (software by Password, Inc). 


\section{Results}

From 1985 to 1999, 1,138 Salmonella spp strains were isolated from stool, blood, urine and other fluids (Table 1). Samples were obtained from 749 children ( 1 to 12 years) and 389 adults, totaling $593(52.1 \%)$ male and 545 (47.9\%) female individuals.

The Salmonella isolated were identified as belonging to 54 serotypes (Table 2). The serotypes most frequently isolated were $S$. I 4,5,12:i:-(21.2\%), $S$. agona $(15.8 \%), S$. enteritidis $(11.2 \%)$ and $S$. typhimurium $(10.0 \%)$, isolated with different frequencies from specific biological materials (Table 1).

S. I 4,512:i:- showed a discrete trend to increased frequency from 1985 to 1999. S. agona was isolated at the highest percentage (26.9\%) among all serotypes, between 1985 and 1989; its relative frequency declined to $13.6 \%$ from $1990-1994$, and to $4 \%$ from $1995-1999$. In contrast, the isolation of $S$. enteritidis increased progressively, and significantly, corresponding to respectively, $<0.1 \%, 5.9 \%$ and $32.3 \%$ over succeeding five year periods (Table 2). The statistical analysis confirming these data is shown in Table 3.

With the exception of tetracycline, the resistance profiles for S. I 4,5,12:i:-, S. enteritidis, $S$. typhimurium, S. dublin, and S. infantis, respectively, showed low resistance to the different antimicrobial substances tested. S. agona strains had comparatively high resistance to most of these drugs (Table 4).

\section{Discussion}

Salmonella serotypes have been isolated and identified as etiological agents of human infections in the State of São Paulo, Brazil since the late 1950s [6]. However, only after 1968 did some of them acquire significant epidemiological importance. We observed an expressive and significant increase in the prevalence of S. enteritidis between 1985 and 1999. These results agree with those of Tavechio et al. [15] who observed a change in the Salmonella serotype prevalence pattern from S. agona to S. enteritidis between 1991 and 1995, with a peak occurring in 1993. In our study, the most frequently isolated Salmonella serotypes in the northeastern region of the State of São Paulo, were S. I 4, 5, 12:i:-, S. agona, S. enteritidis and S. typhimurium.

Similarly, in a retrospective (1991-1995) study, Tavecchio et al. [15] showed that $S$. I 4, 5, 12:i:- was the second most prevalent serotype isolated from cases of salmonellosis. The reason for the high level of isolation of this serotype in Brazil has not yet been determined and speculations about its sources are difficult. S. I 4, 5, 12:i:- apparently was more invasive than other prevalent serotypes, but fortunately it has a low resistance profile.

According to Pessoa et al. [12], S. typhimurium predominated in the State of São Paulo, Brazil between 1970 and 1976 , when it represented $77.7 \%$ of the serotypes isolated from clinical human samples. In other epidemiological studies, Calzada et al. [21] found that between 1977 and 1982, S. typhimurium still had a high $(69.3 \%)$ isolation rate, followed by $S$. agona (16.1\%), whereas at the end of the 1970s S. agona had been the predominant serotype [8].

In our study, S. agona was found to be the most prevalent serotype between 1985 and 1989, comprising $26.9 \%$ of the isolated strains; however, as shown in Tables 2 and 3 , a large decrease in its isolation rate occurred from 1990 to 1999. An expressive and significant increase in the isolation of $S$. enteritidis from clinical samples was detected in the northeastern region of the State of São Paulo, Brazil between 1985 and 1999. This change agrees with the low percentage of S. enteritidis isolated during earlier decades [21,22]. A retrospective analysis carried out in Belgium [23] between 1973 and 1992 showed a similar change in epidemiology, with Enteritidis predominating over $S$. typhimurium ( $43.8 \%$ vs $32.1 \%$, respectively). Miller \& Pegues [24], reported that in the USA, the isolation rate of S. enteritidis increased from $5 \%$, recorded in 1974 , to $26 \%$, recorded in 1994 . Similar findings were reported by Gutiérrez-Cogco et al. [25] who found a gradual increase in the isolation of the $S$. enteritidis serotype between 1990 and 1993 in Mexico. In 1994, S. enteritidis was considered to be an emergent pathogen in Chile [26], where increased numbers of clinical infection of adults and young children caused by this serotype were notified, comprising 478 cases 
Table 1. Absolute figures and percentages of Salmonella serotypes isolated, according to their sources

\begin{tabular}{|c|c|c|c|c|c|c|}
\hline \multirow[t]{2}{*}{ Source } & \multicolumn{6}{|c|}{ Serotypes } \\
\hline & S. I 4,5,12: i: - & S. agona & S. enteritidis & S. typhimurium & Others & All \\
\hline Stool & $56 / 64.7 \%$ & $150 / 83.3 \%$ & $107 / 83.6 \%$ & $85 / 74.6 \%$ & $366 / 77 \%$ & $864 / 75.9 \%$ \\
\hline Blood & $46 / 19.1 \%$ & $9 / \quad 5.0 \%$ & $18 / 14.0 \%$ & $23 / 20.1 \%$ & $71 / 14.9 \%$ & $167 / 14.7 \%$ \\
\hline Urine & $10 / \quad 4.1 \%$ & $5 / \quad 2.7 \%$ & $2 / \quad 1.6 \%$ & $1 / \quad 0.9 \%$ & $14 / \quad 2.9 \%$ & $32 / 2.8 \%$ \\
\hline Others & $29 / 12.1 \%$ & $16 / \quad 9.0 \%$ & $1 / \quad 0.8 \%$ & $5 / \quad 4.4 \%$ & $24 / \quad 5 \%$ & $75 / \quad 6.6 \%$ \\
\hline Total & $241 / 100.0 \%$ & $180 / 100.0 \%$ & $128 / 100.0 \%$ & $114 / 100.0 \%$ & $475 / 100.0 \%$ & $1,138 / 100.0 \%$ \\
\hline
\end{tabular}

in 1994 and 432 in 1995. According to Reis et al. [27], mapping of the geographic distribution of Salmonella serotypes in Brazil between 1992 and 1997 showed a more frequent occurrence of $S$. enteritidis and S. typhimurium in the southern region, of S. agona and $S$. hadar in the northeast, of S. typhi and S. infantis in the southeast and Panama in the north. These authors suggested that the prevalence of the $S$. enteritidis serotype in the southeast region is caused by a cosmopolitan phenomenon.

S. enteritidis was the only serotype that increased steadily during the period studied. It is possible that this increase is linked to the rapid growth of international trade in agricultural food products, facilitating the dissemination of new Salmonella serotypes, changes in types of food consumed, outbreaks of food poisoning, sporadic cases associated with family outbreaks and increased salmonellosis in acquired immunodeficiency syndrome patients [24, 28]. A possible worldwide increase of $S$. enteritidis in forthcoming years would be a cause of public health concern and a challenge to the epidemiologist and to clinical treatment, especially due to the eventual appearance of multi-resistant and invasive strains of these bacteria.

$S$. typhimurium, the most commonly reported pathogenic serotype of Salmonella in humans, was isolated at a low frequency $(10 \%)$ over the three 5year intervals examined in this study; however, when only the isolation from blood is considered, this percentage reaches $20 \%$, which is a high percentage in developing countries. Nevertheless, the incidence of $S$. typhimurium remained relatively constant (Tables 2 and 3), probably because of the substantial rise in the isolation of Enteritidis [29]. It has been proposed that the $S$. enteritidis epidemy could be caused by the clonal expansion of a single, more virulent form of $S$. enteritidis [29].

Antimicrobial therapy is contraindicated in cases of non-complicated salmonella gastroenteritis. However, the current occurrence of multiresistant strains advises its use in high risk groups like newborns, the elderly, as well as in cancer, sickle cell disease, AIDS, transplanted and joint disease patients [24].

Although antimicrobial resistance among human nontyphoid salmonella isolates shows a worldwide trend towards increase, in our study the resistance profile of the majority of strains examined showed that they were sensitive to nearly all drugs tested. Low to moderate resistance rates were observed for serotypes $S$. I 4,5,12:i:-, S. enteritidis, $S$. typhimurium, S. dublin and S. infantis (Table 4); similar to the results obtained by Tavechio et al. [16]. $S$. agona showed greater resistance to most antibiotics when compared to the other serotypes; tetracycline was the least effective drug against Salmonella in vitro. A rather low incidence of antimicrobial resistance is generally observed for salmonella serotypes, except for serotypes $S$. agona and $S$. infantis; these data are unexpected in developing countries. It is conceivable that the low degree of resistance to antimicrobial drugs was caused 
Table 2. Salmonella serotypes from human sources, isolated in Ribeirão Preto, SP, Brazil between 1985 and 1999

\begin{tabular}{|c|c|c|c|c|c|c|c|c|}
\hline \multirow[t]{2}{*}{ Strains/year } & \multicolumn{2}{|c|}{ 1985-1989 } & \multicolumn{2}{|c|}{ 1990-1994 } & \multicolumn{2}{|c|}{ 1995-1999 } & \multicolumn{2}{|c|}{ Total } \\
\hline & $\mathbf{N}^{\mathbf{o}}$ & $\%$ & $\mathbf{N}^{0}$ & $\%$ & $\mathbf{N}^{0}$ & $\%$ & $\mathbf{N}^{\mathbf{o}}$ & $\%$ \\
\hline S. I 4,5,12: i: - & 69 & 17.2 & 100 & 22.7 & 72 & 24.2 & 241 & 21.2 \\
\hline S. agona & 108 & 26.9 & 60 & 13.6 & 12 & 4.0 & 180 & 15.8 \\
\hline S. enteritidis & 6 & $<0.1$ & 26 & 5.9 & 96 & 32.3 & 128 & 11.3 \\
\hline S. typhimurium & 35 & 8.7 & 53 & 12.0 & 26 & 8.8 & 114 & 10.0 \\
\hline S. dublin & 18 & 4.5 & 32 & 7.3 & 8 & 2.7 & 58 & 5.1 \\
\hline S. infantis & 27 & 6.7 & 15 & 3.4 & 12 & 4.0 & 54 & 4.8 \\
\hline S. oranienburg & 20 & 5.0 & 19 & 4.3 & 3 & 1.0 & 42 & 3.7 \\
\hline S. hadar & 13 & 3.2 & 23 & 5.2 & 5 & 1.7 & 41 & 3.6 \\
\hline S. typhi & 13 & 3.2 & 10 & 2.2 & 2 & 0.7 & 25 & 2.1 \\
\hline S. panamá & 6 & 1.5 & 14 & 3.2 & 3 & 1.0 & 23 & 2.0 \\
\hline$S$ I I 6,7: -: 1,5 & 12 & 3.0 & 3 & 0.7 & 2 & 0.7 & 17 & 1.5 \\
\hline S. I 4,12: r: - & 5 & 1.2 & 12 & 2.7 & - & 0 & 17 & 1.5 \\
\hline S. choleraesuis & 9 & 2.2 & 5 & 1.1 & 1 & 0.3 & 15 & 1.3 \\
\hline S. anatum & 1 & 0.2 & 6 & 1.4 & 5 & 1.7 & 12 & 1.1 \\
\hline S. I 4,12: i: - & 4 & 1.0 & - & 0 & 7 & 2.4 & 11 & 1.0 \\
\hline S. brandenburg & 5 & 1.2 & 2 & 0.5 & 4 & 2.0 & 11 & 1.0 \\
\hline S. give & 4 & 1.0 & 5 & 1.1 & 1 & 0.3 & 10 & 0.9 \\
\hline S. derby & 2 & 0.5 & 5 & 1.1 & 2 & 0.7 & 9 & 0.8 \\
\hline S. heidelberg & 5 & 1.2 & 1 & 0.2 & 3 & 1.0 & 9 & 0.8 \\
\hline S. saintpaul & 2 & 0.5 & 5 & 1.1 & 2 & 0.7 & 9 & 0.8 \\
\hline S. mbandaka & 1 & 0.2 & 5 & 1.1 & 3 & 1.0 & 9 & 0.8 \\
\hline S. newport & 3 & 0.7 & 3 & 0.7 & 2 & 0.7 & 8 & 0.7 \\
\hline S. bredeney & 4 & 1.0 & 3 & 0.7 & 1 & 0.3 & 8 & 0.7 \\
\hline S. javiana & 1 & 0.2 & 4 & 1.0 & 3 & 1.0 & 8 & 0.7 \\
\hline S. schwarzengrund & - & 0 & 4 & 1.0 & 4 & 2.0 & 8 & 0.7 \\
\hline S. rissen & 2 & 0.5 & 3 & 0.7 & - & 0 & 5 & 0.4 \\
\hline S. cerro & 1 & 0.2 & 1 & 0.2 & 3 & 1.0 & 5 & 0.4 \\
\hline S. adelaide & 3 & 0.7 & 2 & 0.5 & - & 0 & 5 & 0.4 \\
\hline S. ohio & 2 & 0.5 & 3 & 0.7 & - & 0 & 5 & 0.4 \\
\hline S. emek & - & 0 & 3 & 0.7 & 1 & 0.3 & 4 & 0.3 \\
\hline S. sandiego & - & 0 & 1 & 0.2 & 3 & 1.0 & 4 & 0.3 \\
\hline S. inganda & - & 0 & 3 & 0.7 & 1 & 0.3 & 4 & 0.3 \\
\hline S. albany & - & 0 & - & 0 & 4 & 2.0 & 4 & 0.3 \\
\hline S. muenchen & 2 & 0.5 & 1 & 0.2 & - & 0 & 3 & 0.2 \\
\hline S. berta & 3 & 0.7 & - & 0 & - & 0 & 3 & 0.2 \\
\hline S. kingston & 2 & 0.5 & - & 0 & - & 0 & 2 & 0.2 \\
\hline S. butantan & 2 & 0.5 & - & 0 & - & 0 & 2 & 0.2 \\
\hline S. poona & 1 & 0.2 & 1 & 0.2 & - & 0 & 2 & 0.2 \\
\hline S. I 6,8: e, h: & 1 & 0.2 & 1 & 0.2 & - & 0 & 2 & 0.2 \\
\hline S. miami & 2 & 0.5 & - & 0 & - & 0 & 2 & 0.2 \\
\hline S. I 6,8: $\mathrm{z}_{10}:-$ & 2 & 0.5 & - & 0 & - & 0 & 2 & 0.2 \\
\hline S. braenderup & - & 0 & 1 & 0.2 & 1 & 0.3 & 2 & 0.2 \\
\hline S. london & 2 & 0.5 & - & 0 & - & 0 & 2 & 0.2 \\
\hline S. senftenberg & 2 & 0.5 & - & 0 & - & 0 & 2 & 0.2 \\
\hline S. meleagridis & - & 0 & 2 & 0.5 & - & 0 & 2 & 0.2 \\
\hline S. muenster & - & 0 & - & 0 & 1 & 0.3 & 1 & 0.1 \\
\hline S. saphra & 1 & 0.2 & - & 0 & - & 0 & 1 & 0.1 \\
\hline S. glostrup & - & 0 & 1 & 0.2 & - & 0 & 1 & 0.1 \\
\hline S. abaetetuba & - & 0 & 1 & 0.2 & - & 0 & 1 & 0.1 \\
\hline S. morehead & - & 0 & - & 0 & 1 & 0.3 & 1 & 0.1 \\
\hline S. blockley & - & 0 & 1 & 0.2 & - & 0 & 1 & 0.1 \\
\hline S. paratyphi B & - & 0 & - & 0 & 1 & 0.3 & 1 & 0.1 \\
\hline S. montevideo & - & 0 & - & 0 & 1 & 0.3 & 1 & 0.1 \\
\hline S. I 6,7: r: - & - & 0 & - & 0 & 1 & 0.3 & 1 & 0.1 \\
\hline Total & 401 & 100.0 & 440 & 100.0 & 297 & 100.0 & 1,138 & 100.0 \\
\hline
\end{tabular}


Table 3. Chi square $\left(\chi^{2}\right)$ values for prevalent Salmonella serotypes isolated over three 5-year intervals (1985 to 1989,1990 to 1994,1995 to 1999 )

\begin{tabular}{|c|c|c|c|c|c|}
\hline \multirow[b]{2}{*}{ Serotype } & \multicolumn{3}{|c|}{ Years } & \multirow[b]{2}{*}{ Total } & \multirow[b]{2}{*}{ Values of $\chi^{2}$} \\
\hline & 1985-1989 & 1990-1994 & 1995-1999 & & \\
\hline$S$. I 4,5,12: i: - & 69 & 100 & 72 & 241 & $6.09 *$ \\
\hline S. agona & 108 & 60 & 12 & 180 & $69.72 *$ \\
\hline S. enteritidis & 6 & 26 & 96 & 128 & $182.91 *$ \\
\hline S. typhimurium & 35 & 53 & 26 & 114 & $3.27 \mathrm{~ns}$ \\
\hline
\end{tabular}

${ }^{*} \mathrm{p}<0.05$ by $\mathrm{X}^{2}$ test for differences among the three five-year intervals; ns: not significant.

Table 4. Percent antimicrobial resistance values of prevalent Salmonella serotypes, isolated between 1985 and 1999

\section{Serotype}

\begin{tabular}{lcccccc}
\cline { 2 - 6 } Antibiotic & S.I 4,5,12:i:- & S. agona & S. enteritidis & S. typhimurium & S. dublin & S. infantis \\
\hline Ampicillin & 8.7 & 41.2 & 0.8 & 13.2 & 5.2 & 13.0 \\
Tetracycline & 34.9 & 45.5 & 43.8 & 33.4 & 6.9 & 44.5 \\
TMP-SMX & 7.0 & 39.5 & 8.6 & 15.0 & 3.5 & 11.2 \\
Chloramphenicol & 5.0 & 17.3 & 0.8 & 7.9 & 3.5 & 7.4 \\
Cephalothin & 2.5 & 13.9 & 2.4 & 7.0 & 3.5 & 7.4 \\
Cefoxitin & 0.4 & 5.6 & 1.3 & 0.9 & 3.5 & 11.2 \\
Gentamicin & 2.9 & 30.0 & 4.7 & 7.0 & 3.5 & 16.7 \\
Amikacin & 5.5 & 15.0 & 0.8 & 6.2 & 1.7 & 3.7 \\
Tobramycin & 0.8 & 31.2 & 2.4 & 7.9 & 1.7 & 18.5 \\
Nalidixic acid* & 0.8 & 0.6 & 0.8 & 0.9 & 0 & 0 \\
\hline
\end{tabular}

\# TMP-SMX: trimethoprim-sulfamethoxazole. *Evaluated between 1991-1999.

by the fact that a large part of the salmonella infections recorded was acquired in the community rather than in the hospital. Ampicillin, trimethoprimsulfamethoxazole, and chloramphenicol were less effective in the susceptibility test than nalidixic acid.

In conclusion, we found an increasing rate of $S$. enteritidis from 1985 to 1999 in northeastern São Paulo state. The resistance of Salmonella to antimicrobial agents, with the exception of tetracycline, was found to be low for drugs used in the treatment of infectious diarrhoea, apart from Agona, where strains were found to be more resistant to these drugs in comparison to strains of other Salmonella serotypes. The prevalence of Salmonella serotypes isolated in our region over the last 15 years is epidemiologically important, since it discloses the dimension of the social and economic problem represented by this infection in our region, and demonstrates that salmonellosis is a public health problem in Ribeirão Preto, in the state of São Paulo, Brazil. This health problem is not exclusive to our region; salmonellosis has also been a public health problem in the Presidente Prudente region (in the State of São Paulo, Brazil) and in many other countries around the globe, such as the United States, France, Italy and Norway [30-35]. 


\section{References}

1. Pestana B.R. A febre tifóide em São Paulo. An Paul Med Cirurg 1918; $10: 115-7$.

2. Calazans S.C. A febre tifóide em São Paulo. An Paul Med Cirurg 1925; 16:3-23.

3. Lutz A. Reminiscência da febre tifóide. Mem Inst Oswaldo Cruz 1936;31:851-65.

4. Taunay A.E. Adolfo Lutz, bacteriologista. Rev Inst Adolfo Lutz 1955; $15: 57-62$.

5. Farmer III J.J., Kelly M.T. Enterobacteriaceae. In: Balows, A.; Hausler W.J., Herrmann K.L.; Isenberg H.D.; Shadomy H.J. eds. Manual of Clinical Microbiology. Washington, DC: American Society for Microbiology 1991:360-95.

6. Taunay A.E., Fernandes S.A., Tavechio A.T., Neves B.C., et al. The role of public health laboratory in the problem of salmonellosis in São Paulo, Brazil. Rev Inst Med Trop S. Paulo 1996;38:119-27.

7. Ekperigin H.E., Nagaraja K.V. Salmonella. In: Veterinary Clinics of North America: Food Animal Practice 1998:17-29.

8. Orlandi P.P., Silva T., Magalhães G.F., et al. Enteropathogens associated with diarrheal disease in infants of poor urban areas of Porto Velho, Rondônia: a preliminary study. Mem. Inst. Oswaldo Cruz 2001;96:621-5.

9. Boop C.A., Brenner F.W., Wells J.G., Strockbine N.A. Escherichia, Shigella, and Salmonella. In: Murray P.R., Baron E.J., Pfaller M.A, Tenover F.C., Yolken R.H. eds. Manual of Clinical Microbiology, Washington, DC: ASM Press 1999:459-74.

10. Blaha T. Applied Veterinary Epidemiology, Development in Animal and Veterinary Science. 2nd ed. The Netherlands: Elsevier Science Publishers, 343 pp, 1989.

11. Sakai T, Chalermchaikit T. The major sources of Salmonella enteritidis in Thailand. Int J Food Microbiology 1996;31:173-80.

12. Pessôa G.V.A., Irino K., Calzada C.T., et al. Ocorrência de bactérias enteropatogênicas em São Paulo no septênio 1970-76 - Sorotipos de Salmonella isolados e identificados. Rev Inst Adolfo Lutz 1978;38:87-105.

13. Mitchell L., Tauxe R.V. Drug-Resistant Salmonella in the United States: an epidemiologic perspective. Science 1986; $234: 964-9$.

14. Schutze G.E., Flick E.L., Pope S.K., et al. Epidemiology of salmonellosis in Arkansas. South Med J 1995;88:195-9.

15. Tavechio A.T., Fernandes S.A., Neves B.C., et al. Change patterns of Salmonella serovars: increase of Salmonella enteritidis in São Paulo, Brazil. Rev Inst Med Trop S Paulo 1996;38:315-22.
16. Isenberg H.D., Washington II. .FD, Von Graevenitz A. In: Baron S.J., Manual of Clinical Microbiology. American Society for Microbiology, Washington, DC. 1991: 15-28.

17. Ewing W.H. Edwards and Ewing's identification of Enterobacteriaceae. 4th ed. New York: Elsevier, 536 pp, 1986.

18. PopoffM.Y., Le Minor L. Formules antigéniques des sérovars de Salmonella. Paris, Centre Collaborateur OMS de Référence et de Recherche pour les Salmonella 1992:145.

19. National Committee for Clinical Laboratory Standards. Performance standards for antimicrobial disk susceptibility tests. Approved standard M2-A6. National Committee for Clinical Laboratory Standards, Wayne, Pa, 1997.

20. Triola M.F. Introdução à estatística. LTC - Livros técnicos e Científicos, Rio de Janeiro, 320 p, 1999.

21. Calzada C.T., Neme S.N., Irino K., et al. Sorotipos de Salmonella identificados no período 1977-1982, no Instituto Adolfo Lutz, São Paulo, Brasil. Rev Inst Adolfo Lutz 1984;44:1-18.

22. Peresi J.T.M., Almeida A.Z.C., Lima S.I., et al. Surtos de enfermidades transmitidas por alimentos causados por Salmonella enteritidis. Rev Saúde Pública 1998;32:477-83.

23. Le Bacq F., Louwagie B., Verhagen J. Salmonella typhimurium and Salmonella enteritidis changing epidemiology from 1973 until 1992. Eur J Epidemiol 1994; 10:367-71.

24. Miller S.I., Pegues D.A. Salmonella species, including Salmonella typhi. In: Mandell, GL, Bennett JE, Dolin R, Principles and Practice of Infectious Disease. Churchill Livingstone, Philadelphia. p. 2344-2362, 2000.

25. Gutiérrez-Cogco L., Gonzalez-Bonilla, Giono-Cerezo S., Beltra L.G. Principales serotipos de Salmonella identificados en 10703 cepas en Mexico entre 1982 y 1993. Rev Lat-Amer Microbiol 1994;36:221-6.

26. Fica A., Fernandez A., Prat S., et al. Salmonella enteritidis, an emergent pathogen in Chile. Rev Med Chil 1997; 125:544-51.

27. Reis E.M.F., Feitosa D.P., Solari C.A., et al. Sorovares prevalentes de Salmonella de origem humana no período de 1992 a 1997: Resultados do centro de referência nacional de cólera e enteroinfecções (Abstract). In: Program and abstracts: XX Congresso Brasileiro de Microbiologia, Rio de Janeiro, p. 44, 1997.

28. Altekruse S.F., Cohen M.L., Swerdlow D.L. Emerging foodborne diseases. Emerg Infect Dis 1997;3:285-93.

29. Bäumler A.J., Hargis B.M., Tsolis R.M. Tracing the origins of Salmonella Outbreaks. Science 2000;287:50-61.

30. Esper M.R.N.R., Freitas A.M., Fernandes S.A., et al. Salmonella sorotipos identificados das cepas isoladas de pacientes hospitalizados e não hospitalizados, na região de Presidente Prudente, SP, no período de 19781997. Rev Inst Adolfo Lutz 1998;57:45-50. 
31. D’Aoust J. Salmonella. In: Doyle, M.P. (ed), Foodborne microbial pathogens, New York. Marcel Dekker, p. 327445, 1989.

32. Olsen S.J., Bishop R., Brenner F.W., et al. The changing epidemiology of Salmonella: Trends in serotypes isolated from humans in the United States, 1987-1997. J Infect Dis 2001;183:753-61.

33. Gallay A., Vaillant V., Bouvet P., et al. How many foodborne outbreaks of Salmonella infection occurred in France in 1995? Application of the capture-recapture method to three surveillance systems. Am J Epidemiol 2000; $152: 171$.

34. Scuderi G., Fantasia M., Filetici E., Anastasio M.P. Foodborne outbreaks caused by Salmonella in 1991-4. Epidemiol Infect 1996;116:257-65.

35. Kapperud G., Lassen J., Hasseltvedt V. Salmonella infections in Norway: descriptive epidemiology and a case-control study. Epidemiol Infect 1998;121:569-77. 